\title{
The Origins and Course of Psychopathology
}




\section{The Origins and Course of Psychopathology \\ Methods of Longitudinal Research}

Edited by

John S. Strauss and Haroutun M. Babigian

University of Rochester

Rochester, New York

and

Merrill Roff

Professor Emeritus

University of Minnesota

Minneapolis, Minnesota

Plenum Press • New York and London 


\section{Library of Congress Cataloging in Publication Data}

Main entry under title:

The Origins and course of psychopathology.

Includes index.

1. Psychiatry-Longitudinal studies. I. Strauss, John S. II. Babigian, Haroutun. III. Roff, Merrill Flagg, 1909-

RC337.073

[DNLM: 1. Psychopathology. WM100 069]

ISBN-13: 978-1-4684-2357-0 616.8'9'007

$77-2874$

DOI: $10.1007 / 978-1-4684-2355-6$

○ 1977 Plenum Press, New York

Softcover repint of the hardcover 1st edition 1977

A Division of Plenum Publishing Corporation 227 West 17th Street, New York, N.Y. 10011

All rights reserved

No part of this book may be reproduced, stored in a retrieval system, or transmitted, in any form or by any means, electronic, mechanical, photocopying, microfilming, recording, or otherwise, without written permission from the Publisher 


\section{Acknowledgments}

The editors wish to thank Ms. Patti Sanderl, Nancy Ryan, Sue Willis, and Dolores Jones for their assistance and dedication in preparing this volume. We also wish to thank Drs. Martin Katz and Robert Hirschfeld of the Clinical Research Branch, National Institute of Mental Health; the Department of Psychiatry of the University of Rochester, Dr. Lyman C. Wynne, Chairman; Roche Laboratories, and the Sandoz Corporation for their support of the conference from which this volume is derived.

In addition, we acknowledge the following:

Figure 1, Chapter 1. Reprinted by permission of the authors and the editor, from Weissman, M.M. and Kasl, S.V.: Help seeking in depressed outpatients following maintenance therapy. British Journal of Psychiatry, vol. 129, pp. 252260, 1976.

Figure 1, Chapter 5. From Dohrenwend, B.P.: The social psychological nature of stress: A framework for causal inquiry. Journal of Abnormal and Social Psychology, vol. 62, pp. 294302, 1961. Copyright 1961 by the American Psychological Association. Reprinted by permission.

Table 2 and Figure 1, Chapter 12. Reprinted by permission of the authors and the editor from Hogarty, G.E.; Goldberg, S.C.; Schooler, N.R.; and Ulrich, R.F.: Drug sociotherapy in the aftercare of schizophrenic patients. Archives of General Psychiatry, vol. 31, pp. 603-608, 1974. Copyright 1974, American Medical Association.

Figure 1, Chapter 14. From Gunderson, J.; Carpenter, W.T., Jr.; Strauss, J.S.; and Scott, W.: Borderline patients - A comparative study. American Journal of Psychiatry, vol. 132 , pp. 1257-1264, 1975. Copyright 1975, the American Psychiatric Association. Reprinted by permission. 
Table 2, Chapter 14. Reprinted by permission of the authors and the editor, from Carpenter, W.T.; Strauss, J.S.; and Bartko, J.J.: A flexible system for the identification of schizophrenia: A report from the International Pilot Study of Schizophrenia. Science, vol. 182, pp. 1275-1278, 1973. Copyright 1973 by the American Association for the Advancement of Science.

Chapter 16. This paper has been published as part of a series of program reports of the National Institute on Drug Abuse supported research on evaluation of treatment for drug abuse, in Sells, S.B. and Simpson, D.D., Eds., The Effectiveness of Drug Abuse Treatment, Volume III. Further Studies of Drug Users, Treatment Typologies, and Assessment of Outcomes. During Treatment in the DARP. Cambridge, Mass.: Ballinger Publishing Company, published in June, 1976.

This work has also been supported in part by NIMH Grant No. MH-00006-01. 


\section{Preface}

The Society for Life History Research in Psychopathology is a group of investigators from many disciplines who share an interest in studying the longitudinal aspects of psychiatric disorder. Sociologists, psychologists, statisticians, psychiatrists, epidemiologists, and others each bring to the study of life history the expertise and vantage point arising from his or her unique training and experience.

This volume, the fifth in a series, is devoted to exploring the methods used to contribute to the understanding of the complex unfolding of a human life as it avoids, copes with, or succumbs to psychiatric disorder. We hope that by describing these methods, their current status, advantages, and shortcomings, this volume can serve as a guidepost to all who are involved in our field to help understand it further and to generate solutions for the many crucial problems we face.

M.R. 


\section{Contents}

Introduction . . . . . . . . . . . . . . I

John S. Strauss, Haroutun M. Babigian, and Merrill Roff

\section{SECTION I}

CONTROLLED VS. NATURALISTIC APPROACHES

CHAPTER 1

Controlled vs. Naturalistic Experiments:

Application of the Life Table Method . . . . . . 7

Myrna M. Weissman

CHAPTER 2

The Psychiatric Case Register: A Versatile

Device for the Application of Multiple

Methodological Approaches . . . . . . . . . 23

Haroutun M. Babigian and Dolores B. Jones

CHAPTER 3

A Survey of Issues Related to the Analysis

of Observational Data in Longitudinal Research . . 43

John E. Overall

CHAPTER 4

A Combined Thirty-Five Year Follow-Up and Family Study of Schizophrenia and Primary

Affective Disorders: Sample Selection, Methodology of Field Follow-up, and Preliminary

Mortality Rates . . . . . . . . . . . . 61

Ming T. Tsuang and George Winokur

Discussion of Section I . . . . . . . . . 79 
SECTION II

LIFE EVENTS

CHAPTER 5

The Conceptualization and Measurement of

Stressful Life Events: An Overview of the

Issues . . . . . . . . . . . . . . . 93

Bruce P. Dohrenwend and Barbara S. Dohrenwend

CHAPTER 6

Remembering Life Events . . . . . . . . . 117

Eberhard Uhlenhuth, Mitchell D. Balter,

Ronald S. Lipman, and Shelby J. Haberman

CHAPTER 7

Anticipation and Control of Stressful Life

Events . . . . . . . . . . . . . 135

Barbara S. Dohrenwend

Discussion of Section II . . . . . . . . . 187

SECTION III
STUDIES OF CHILDREN AT RISK

CHAPTER 8

Longitudinal vs. Cross-Sectional Research in

the Study of Children at Risk for

Psychopathology . . . . . . . . . . . 193

Norman Garmezy and Vernon T. Devine

CHAPTER 9

Prospective Studies to Investigate

Behavioral Change . . . . . . . . . . 223

Michael Rutter 
CHAPTER 10

The Rochester Adaptive Behavior Inventory:

A Parallel Series of Instruments for Assessing

Social Competence during Early and Middle

Childhood and Adolescence . . . . . . . 249

Fredric H. Jones

Discussion of Section III . . . . . . . . 282

SECTION IV

FOLLOW-UP STUDIES OF PSYCHIATRIC PATIENTS

CHAPTER 11

Longitudinal Research on Psychopathology

in Psychiatric Patients: Some Assets and

Liabilities . . . . . . . . . . . . . 293

Robert Cancro

CHAPTER 12

Life History Characteristics of Responders

to Drug and Social Therapy in Schizophrenia . . 303

Solomon C. Goldberg, Nina R. Schooler, and Gerard E. Hogarty

CHAPTER 13

Long-Term Follow-Up of Juvenile and Adult

Delinquency with Samples Differing in Some

Important Respects: Cross-Validation within

the Same Research Program . . . . . . . 323 Merrill Roff

CHAPTER 14

Methodological Issues in the Study of Outcome . 345 William T. Carpenter and John S. Strauss

Discussion of Section IV . . . . . . . . . . 371 


\section{SECTION V \\ RELATIONSHIPS AMONG VARIABLES AFFECTING DEVELOPMENT AND COURSE OF PSYCHOPATHOLOGY}

CHAPTER 15

Detecting Predictors of Rare Events:

Demographic, Family and Personal Deviance as

Predictors of Stages in the Progression

toward Narcotic Addiction . . . . . . . . 379

Lee N. Robins, Darlene H. Davis, and

Eric Wish

CHAPTER 16

Problems of Conceptualization and Design in

Research on the Evaluation of Treatment for

Drug Abuse . . . . . . . . . . . . 407 S.B. Sells

Discussion of Section V . . . . . . . . . 439

SUBJECT INDEX . . . . . . . . . . . . . . . 449 